\title{
SZCZYRKOWSKA WSPOMOŻYCIELKA I KRÓLOWA
}

Ikona jest widzialnością Niewidzialnego

(Jan Damasceński)

W Szczyrku miasteczku Beskidu Śląskiego, pod patronatem Papieskiej Akademii Teologicznej w Krakowie (Wydział Teologiczny, Katedra Mariologii) oraz salezjańskiego sanktuarium Matki Bożej Królowej Polski w Szczyrku na Górce, zorganizowana została w dniach 9-10 V 2008 r. sesja naukowa na temat: Szczyrkowska Wspomożycielka i Królowa - wiara, teologia, duszpasterstwo. Przed mającą się odbyć dnia 21 IX 2008 r. koronacją tamtejszego cudownego obrazu Matki Bożej Królowej Polski, pracujący tam salezjanie, na czele z kustoszem sanktuarium (od 2001 r.) - ks. Markiem Dąbkiem, na zorganizowanej sesji naukowej umożliwili jej uczestnikom poznanie historii placówki duszpasterskiej, przybliżając również przy tej okazji w ogóle tematykę objawień maryjnych i koronacji obrazów Matki Bożej w aspekcie teologicznym, liturgicznym i duszpasterskiem.

Wystąpienia sesyjne odbywały się w odnowionej świątyni maryjnej. Na przebieg sesji złożyło się 6 referatów pracowników naukowych Papieskiej Akademii Teologicznej, Uniwersytetu Kardynała Stefana Wyszyńskiego w Warszawie i salezjanina - ks. Krzysztofa Pyzika.

Miejsce objawień maryjnych w lipcu 1894 r. na zboczu beskidzkiego Klimczoka tamtejsi wierni upamiętnili budową drewnianej kapliczki. Zadbali także o wyposażenie kaplicy w niezbędne przedmioty liturgiczne. Powołany w 1912 r. Komitet Kaplicy przejął opiekę nad tym miejscem objawień i rozpoczął gromadzenie środków na budowę murowanej kaplicy, którą w następnych dziesięcioleciach wielokrotnie rozbudowywano. Odczuwali wszyscy potrzebę skierowania do kaplicy na stałe kapłana, o którego zabiegali mieszkańcy Szczyrku. Odpoczywający tam w 1937 r. salezjanin ks. Józef Omasta (1907-1967) rozpoczął w tamtejszej kaplicy odprawiać Msze święte. W maju następnego roku Komitet uwzględniając 
prośby miejscowej ludności przekazał salezjanom kaplicę i teren pod lokalizację domu zakonnego, którego budowę rozpoczął ks. Omasta. Do wybuchu wojny zdołano ukończyć prowizoryczny barak z kilkoma pokojami. W czasie wojny chronili się tam salezjanie oświęcimscy, ścigani przez Gestapo, których chętnie przyjmował ks. Omasta. Zgromadzony do wojny materiał budowlany zrabowali okupanci. Placówka salezjańska w Szczyrku należała do Zakładu im. Ks. Bosko w Oświęcimiu. Erekcja domu zakonnego pw. Matki Bożej Częstochowskiej nastąpiła 13 IX $1963 \mathrm{r}^{1}$

Po drugiej wojnie światowej rektor tamtejszej kaplicy, ks. Hipolit Władarz (1907-1971) z pomocą współpracowników (ks. Bronisława Szymańskiego, ks. Pawła Rupika, ks. Kazimierza Masłowskiego) podjął w 1948 r. rozbudowę murowanej świątyni Najświętszej Wspomożycielki Szczyrkowskiej i budowę domu. Świątynia ostatecznie uzyskała obecny kształt architektoniczny i była systematycznie wyposażana i upiększana przez kolejnych przełożonych tamtejszego domu zakonnego i duszpasterzy salezjanów ${ }^{2}$.

Biskup Karol Wojtyła, nawiedzając dnia 19 VII 1959 r. parafię św. Jakuba w Szczyrku, odwiedził kościół na Górce. Acybiskup metropolita Gnieźnieński i Poznański, Prymas Polski uzasadniając kult i rangę tego miejsca oraz promulgując w 1965 roku dotychczasowe 4 odpusty kościołowi na Górce: 2 lutego (Ofiarowanie NMP), 3 maja(Królowej Polski), 15 sierpnia (Wniebowzięcie NMP), 8 września (Narodzenie NMP), dodał piąty odpust na dzień 31 stycznia (liturgiczne święto św. Jana Bosko) $)^{3}$.

Kościół Matki Bożej Królowej Polski został konsekrowany i podniesiony do godności lokalnego sanktuarium przez biskupa diecezji bielsko-żywieckiej - ks. Tadeusza Rakoczego podczas uroczystości Jubileuszowego Odpustu dnia $3 \mathrm{~V}$ 1994 r., w setną rocznicę objawień i kultu Matki Bożej na Górce.

W latach 1986-1992 powyżej sanktuarium w Szczyrku wybudowany został salezjański dom młodzieżowy Dom Pielgrzyma. Dysponuje 100 miejscami noclegowymi z kaplicą dla wypoczywających; głównie dzieci i młodzieży. Oprócz zorganizowanych grup i osób indywidualnych pragnących odpocząć w Beskidach, których Dom przyjmuje, organizowane są rekolekcje i dni skupienia dla młodzieży.

$* * * * *$

${ }^{1}$ Po przymusowej ucieczce ks. Omasty w listopadzie 1941 r. ze Szczyrku jego miejsce zają ks. Hipolit Władarz; Szczyrkowska Górka, „Pokłosie Salezjańskie”, 26 (1948) nr 11, s. 235-237; A. Świda, Towarzystwo Salezjańskie. Rys historyczny, Kraków 1984, s. 184-185; J. Ślósarczyk, Historia Prowincji św. Jacka Towarzystwa Salezjańskiego w Polsce, t. 3, Pogrzebień 1966, s. 47-51 [mps].

${ }^{2}$ Wystrój wnętrza kościoła w drzewie (ołtarz główny, konfesjonały, stacje Drogi Krzyżowej) wykonał w latach 1960-1963 Józef Kruczek ze Szczyrku, według projektu salezjanina - ks. Adama Skałbani. Ołtarze boczne św. Józefa i św. Jana Bosko wykonano w Łodzi w 1964 r. Mozaikę tajemnic różańcowych na ścianach bocznych zaprojektował i wykonał w 1973 r. Stanisław Jakubczyk z Krakowa. J. Krawiec, Powstanie Towarzystwa św. Franciszka Salezego orazjego organizacja i dziatalność na ziemiach polskich, Kraków 2004, s. 154.

${ }^{3}$ Dekret Prymasa Polski dla kościoła Matki Bożej w Szczyrku, nr 138/65 od 4879/65 z dnia 8 I 1965 r. - Warszawa. 
Przybyłych salezjanów, duchowieństwo, nieliczne siostry zakonne i miejscowych wiernych powitał w kościele na Górce pasterz diecezji bielsko-żywieckiej, biskup Tadeusz Rakoczy. Usprawiedliwił swoją absencję w czasie obrad, zapewniając o duchowej obecności na Górce w tym czasie. Pasterz diecezji mówił, iż nasza Matka spotyka się $\mathrm{z}$ nami w pewnych miejscach. Są to m.in. kapliczki i świątynie, do których należy sankutarium na Górce. Tu przybywają rzesze pielgrzymów, którzy z Matką Bożą pragną omawiać sprawy osobiste, rodzinne, narodowe. Kościół głosi, że fundamentalne Objawienie zostało dokonane w Jezusie Chrystusie, a późniejsze objawienia osądza indywidualnie. Jeśli objawienie szczyrkowskie Kościół uznaje za autentyczne, potwierdzi to aktem koronacji cudownego obrazu Matki Bożej. Biskup zakończył słowami: Trzeba umieć przełożyć wydarzenie liturgiczne, jakim jest koronacja, na nasze życie w Kościele, a to winno zaowocować pogłębieniem życia duchowego wiernych.

Przełożony (inspektor) salezjańskiej Prowincji św. Jacka Odrowąża, do której należy placówka szczyrkowska - ks. dr Marek Chrzan, współgospodarz sesji, naświetlił zaangażowanie placówek prowincji w promocji tego miejsca kultu maryjnego. Gdy 31 I 2006 r. podpisany został przez prefekta Kongregacji Kultu Bożego i Sakramentów dokument zezwalający na koronację koronami papieskiemi łaskami słynącego obrazu Najświętszej Maryi Panny z Dzieciątkiem Jezus, którą wierni w Szczyrku czczą pod wezwaniem Królowej Polski, dało to możliwość zainaugurowania roku przygotowań do uroczystości koronacji. Rok przygotowania liturgicznego rozpoczęli salezjanie w prowincji we wrześniu 2007 roku. Dnia 9 IV 2008 r. Ojciec Święty Benedykt XVI poświęcił w Rzymie korony papieskie do obrazu Matki Bożej. Przełożony prowincji poinformował słuchaczy, że w domach prowincji krakowskiej salezjanie zorganizowali „dni szczyrkowskie”, w czasie których mówiono o Maryi i Jej kulcie, głównie na przykładzie szczyrkowskiej Górki ${ }^{4}$. W tym duchu przeżywano inspektorialne Święto Młodzieży - tzw. Savionalia, zorganizowane w dniach 1-3 maja 2008 r. w salezjańskim Wyższym Seminarium Duchownym Towarzystwa Salezjańskiego w Krakowie, przy ul. Tynieckiej 39 (na „Łosiówce”). Jako szczególniejsze wydarzenie o charakterze naukowym, intelektualnym i duchowym wskazał ksiądz inspektor zorganizowaną sesję, która odbywa się w roku, kiedy upływa 70 lat posługi salezjanów w Szczyrku na Górce oraz w 20-lecie (24 V 1988 r.) organizowanych w sankuarium modlitewnych czuwań z Matką Bożą z 24 na 25 dzień miesiąca, od maja do października każdego roku.

Odowiedzialny za przebieg sesji - ks. prof. dr hab. Wojciech Życiński, salezjanin, kierownik Katedry Mariologii na Wydziele Teologicznym Papieskiej Akademii Teologicznej, przedstawiłzaproszonych prelegentów, którzy wystapili w piątkowe popołudnie i dnia następnego.

Prezes Polskiego Towarzystwa Mariologicznego - ks. dr Teofil Siudy (UKSW i Instytut Teologiczny w Częstochowie) mówił na temat: Tematyka objawień maryjnych w nauczaniu Jana Pawła II. Przedstawił doktrynę teologiczną objawień,

${ }^{4}$ Tej tematyce poświęcone zostały czytanki na nabożeństwa majowe (Santuarium Królowej Polski w Szczyrku na Górce, Kraków 2008) autorstwa księży: Henryka Skórskiego i Wojciecha Życińskiego. 
pobożność, duszpasterstwo i aspekt pastoralny maryjnego nauczania papieskiego. Ksiądz prof. dr hab. Wojciech Życiński w referacie: Objawienia maryjne XX wieku zatwierdzone przez Kościót. Istota przesłania, ukazał objawienia prywatne na tle objawienia samego Chrystusa, które jest zobowiązujące dla wszystkich wiernych na drodze do zbawienia. Natomiast objawienia prywatne i ich treść nie zobowiązują do takiej wiary, poza tymi osobami którym zostały przekazane. Ostatni mówca piątkowego popołudnia ks. mgr Krzysztof Pyzik, w wystapieniu: Objawienia Matki Bożej w Szczyrku, ukazał objawienia Matki Bożej na stoku Klimczoka, na tzw. Przykrej Kępie w 1894 r. tamtejszej mieszkance, dwunastoletniej Juliannie Pezda ${ }^{5}$ jej dwu rówieśniczkom. Matka Boża poleciła wówczas szkaplerz, odmawianie modlitwy „Anioł Pański”, śpiewanie Godzinek, poleciła wybudować na tym miejscu kaplicę a w przyszłości klasztor, w którym będzie się odprawiać „dużo Mszy świętych”. Paulin, ojciec prof. dr hab. Tadeusz Dionizy Łukaszuk (PAT), mówił o aspekcie teologicznym koronacji obrazów Matki Bożej. Ks. prof. dr hab. Stefan Koperek (PAT) ukazał aspekt liturgiczny koronacji obrazów Matki Bożej. Ojciec prof. dr hab. Zachariasz Jabłoński (UKSW) omówił aspekt duszpasterski koronacji obrazów maryjnych.

Obrzęd koronacji dokonuje się w czasie Mszy św., nieszporów lub specjalnej liturgii Słowa. Można koronować wyłącznie wizerunek Matki Najświętszej. Jeśli jest z Dzieciątkiem, to najpierw koronuje się Dzieciątko. Koronacji dokonuje biskup, papież lub jego delegat. Jest ona zwieńczeniem przesłania maryjnego skierowanego do wiernych, potwierdzeniem jego autentyczności przez Kościół oraz wyrazem i dowodem pobożności ludu.

Dotychczasowa wiara i pobożność maryjna wiernych opiera się na przeświadczeniu, że „Kościół wybudowany na Górce nie jest dziełem przypadku, ani nie był specjalnie potrzebny, lecz powstał na wyraźne życzenie Najświętszej Maryi Panny"6.

\footnotetext{
${ }^{5}$ Julianna mieszkała w innej części Szczyrku, pod Skrzycznem. Spowiadała się u salezjanów na Górce. Ks. Bronisław Szymański z Wisły spotykał Juliannę w kościele na Górce. Julianna zmarła w 1956 roku, pochowana na cmentarzu parafialnym w Szczyrku.

${ }^{6}$ Fragment z kroniki szczyrkowskiej z 1963 r. zapisany przez ks. Bronisława Piroga. Cyt. za S. Skórski, W. Życiński, Sanktuarium Królowej Polski w Szczyrku na Górce, Kraków 2008, s. 30-31.
} 